Hevko Ihor Vasilievich. Formation of ready for professional activity of future service favorites. Journal of Education, Health and Sport. 2020;10(2):107-113. eISSN 2391-8306. DOI http://dx.doi.org/10.12775/JEHS.2020.10.02.014

https://apcz.umk.pl/czasopisma/index.php/JEHS/article/view/JEHS.2020.10.02.014

https://zenodo.org/record/3677414

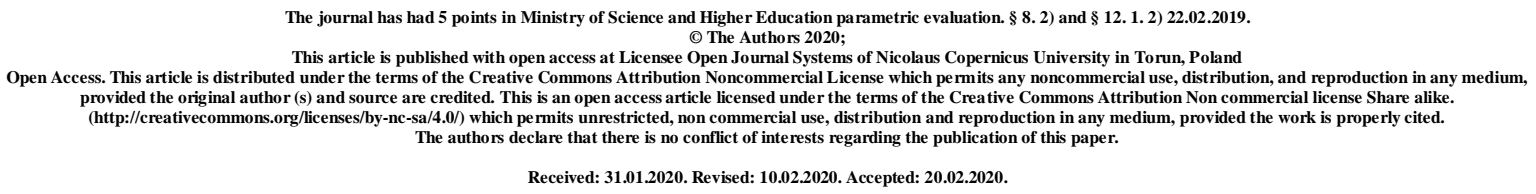

UDK 378.147

\title{
FORMATION OF READY FOR PROFESSIONAL ACTIVITY OF FUTURE SERVICE FAVORITES
}

\author{
Ihor Vasilievich Hevko
}

\section{Ternopil National Pedagogical University Volodymyr Hnatyuk}

\begin{abstract}
The article examines the readiness for professional activity of future specialists in the service sector, a certain systematic approach to training, which should become the basis for its modernization. In addition, appropriate mechanisms are needed to ensure that the system responds to environmental challenges. Vocational education is not just a means of obtaining and disseminating the necessary knowledge, but an essential factor in the adaptation of an individual in a constantly changing society. In the article it is proved that the sphere of services, in which professional competence - the ability to apply knowledge and skills for successful activity - becomes the main and determining factor - allows to successfully solve the actual tasks related to the motivation of the specialist of the sphere of services. The content of the professional training of specialists is defined in such component of the state industry standard as the educational and professional training program. Therefore, the analysis of the state of professional training of future specialists in the field of service in forming their readiness for professional interaction with service consumers shows that the practical training does not correspond to the requirements of employers, namely: insufficient ability to deal positively with conflict situations; uncertainty about professional activities.
\end{abstract}


Key words: readiness; sphere of services; formation of professional activity; professional training.

\title{
ФОРМУВАННЯ ГОТОВНОСТІ ДО ПРОФЕСІЙНОЇ ДІЯЛЬНОСТІ МАЙБУТНІХ ФАІВЦІВ СФЕРИ ОБСЛУГОВУВАННЯ
}

\author{
I. В. Гевко \\ Тернопільський національний педагогічний університет \\ імені Володимира Гнатюка
}

\begin{abstract}
Анотація
Стаття присвячена актуальній на сьогоднішній день проблеми-професійної підготовки майбутніх фахівців сфери послуг. У статті описані основні особливості організації професійної підготовки фахівців сфери послуг, які формують комплекс професійно-значущих умінь. Описується можливість теоретико-педагогічної підготовки майбутніх фахівців сфери послуг. В статті акцентовано, професійні уміння фахівців сфери обслуговування мають складну структуру і формуються в процесі навчання і подальшої професійної діяльності. Високий рівень сформованості професійних умінь фахівців сфери обслуговування буде сприяти становленню висококваліфікованого фахівця на ринку праці, при дотриманні всіх педагогічних умов формування професійних умінь.
\end{abstract}

Ключові слова: підготовка; майбутній фахівців; сфера послуг; вміння; процес навчання.

Statement of the problem. The professional training of specialists in various fields in any country is an extremely important task of the state. Its resolution becomes more acute, depending on how close certain specialists are to the sphere of social activity. Unfortunately, as the analysis of the real situation showed, a considerable part of social workers in the professional-personal plan turned out to be unprepared for multifunctional, multi-purpose activity in the conditions of dynamic society today, since it requires mobilization of personal and micro-social resources of a person in a diverse and contradictory social environment.

Analysis of recent research and publications. In the scientific literature, analyzing the structure of personality's readiness for professional activity depending on its content, scientists identify three main components of readiness: cognitive, operational and 
motivational. Other components are determined by the specific content. Thus, S. Vorobyov believes that the structure of students' willingness to solve creative tasks combines motivational, content, personal and professional components. O. Boyko identifies five components in the structure of future masters' readiness for management activity: motivational, value, cognitive, activity and personal $[1,5]$. Defining the concept of students' readiness - future social workers - for professional activity requires a more detailed analysis of the essence of readiness, especially from the point of view of psychology, namely: readiness is interpreted as a condition or property of a person who can and wants to do something; the state for which everything is done is ready for something. Most authors view it as a certain mental state. In most studies, the category of "readiness" is correlated with the purpose and end result of training. The basis of this opinion is the position that the effectiveness of any activity is determined by psychological and practical readiness for it (M. Dyachenko, L. Kandybovich, N. Levitov, K. Makogon, O. Moroz, O. Savitskaya, D. Uznadze) .

The issue of readiness for activity is considered in the scientific works of many scientists from the standpoint of different approaches and at different levels: personality and activity (L. Bozhovich, I. Zimnaya, L. Kandibovich, A. Lynenko, V. Molyako, A.Ponukalin; personal (A. Golomstok, P. Gornostay, N. Zakharov, E. Klimov, V. Symonenko); functional (R. Ovcharov, A. Osnitsky, N. Pryazhnikov, D. Uznadze) and transformative-practical (K. Abulkhanov-Slavsk). In the scientific researches the psychological aspect of readiness is considered, its content, structure and ways of its formation are defined; much less attention is paid to the pedagogical aspect of professional readiness. Thus, A. Slastonin $[4,3]$ considers readiness for professional activity to be one of the basic characteristics of a social worker's personality. He stresses the particular relevance of the task of forming the readiness of students studying in the specialty "social work" for their professional activity.

Purpose of the research: formation of readiness of future social workers for professional activity in higher technical educational establishments.

Basic material. In addition, a number of researchers note that high school graduates with a degree in social work are experiencing difficulties with the psychological plan that arise because the "model of professional activity" that is formed in their minds during their college years is inconsistent with the real environment, in which they have to start a professional work of a social worker. The reasons for this are mainly because in the vocational training of social work students, the informative side of learning predominates. The personality of the future social worker, the development of his professional-ethical and 
spiritual-intellectual potential often fall out of sight of the organizers of the educational process.

Throughout its existence, the vocational education and training system has for the most part performed a single function - providing the needs of production infrastructure with skilled workers. The level of development of vocational education clearly reflects the quality of the working potential and, accordingly, the socio-economic situation in the industries and services. Today, the role of the service sector in the world economy is growing significantly. With the rapid development of the services sector, the labor market is placing increasing demands on the quality of training of relevant specialists. The range of services offered and the number of employees employed in this field of activity are expanding. This is due, first of all, to the development of new technologies and changes in the level of life of modern society. The needs of the newest consumer are becoming more demanding for quality of service and service. Today's market environment requires service professionals who have not just specialized training, but professionals who are able to make complex professional decisions, solve atypical production tasks, ensuring high quality of service and customer satisfaction. Therefore, the consumer has a great influence on the development of business in the service sector. Training of skilled workers, in particular in the field of services, is carried out in accordance with the List of vocations of vocational education, the content of which has substantially decreased in recent years. This is due to the orientation of vocational education on the preparation of competitive graduates, capable of rapid adaptation in the labor market and the fulfillment of various vocational-oriented tasks in related fields of activity.

At present, in line with the National Doctrine of Educational Development, one of the main tasks is to realize the constitutional right and equal opportunities of citizens to obtain quality free education, which provides:

- meeting the needs of a person in highly qualified professional educational services to increase the competitiveness of graduates in the labor market;

- Improvement of conditions for quality education, students' acquisition of practical skills, development of their creative and professional abilities with simultaneous increase of educational level;

- involvement of young people in full-fledged productive work and formation of high morals and respect for the law, etc .;

- meeting the needs of society to prepare skilled labor for all sectors of the economy.

The changes that are taking place in Ukrainian society have touched upon the spheres of services and social and cultural services, which require theoretical understanding of the 
ongoing processes, as well as the training of specialists able to work in new conditions. Accordingly, it is possible to distinguish the key aspects that determine the current level of professional training of the future specialist of the service industry:

- formation of specialist knowledge and skills, in accordance with the specifics of the future profession;

- formation of stable cognitive, psychomotor, effective work skills necessary for the professional fulfillment of professional duties in a specific workplace;

- development of the employee's personality, ensuring his professional competence, professional and social mobility.

Thus, we are talking about a systematic approach to vocational training, which should be the basis for its modernization. In addition, appropriate mechanisms are needed to ensure that the system responds to environmental challenges. Vocational and technical education is not just a means of obtaining and disseminating the necessary knowledge, but an essential factor in the adaptation of an individual in a constantly changing society.

Education successfully realizes a cultural function in the formation of personality, as it becomes a structure that influences the way of life of a person, allows the proper preparation of the individual for productive activity, becomes the basis of social activity, plays a protective role in terms of protecting the worker from possible changes in the labor market. The value of the service sector in the global economy is constantly growing, leading to a number of new challenges.

The service industry, in which professional competence - the ability to apply knowledge and skills for successful activity - is the main and decisive factor, enables successful completion of current tasks related to the motivation of the service professional.

In this regard, it becomes necessary to take full account of new trends in the functioning of the service sector in the formation of a set of necessary professional competencies of the future qualified specialist. The most important factors for improving the quality of training of service professionals are the following:

- the need for theoretical training of specialists while simultaneously developing entrepreneurial skills;

- development and formation of scientific and methodological support, which makes it possible to create the necessary methodological base for the training of professional personnel; - improving the quality of professional training and reducing the period of adaptation of graduates in the workplace. 
Ukraine has established a network of educational institutions that train service professionals. Therefore, an increasing number of non-core HSEs receive licenses for training in the professional training of service professionals [2]. Accordingly, the need to develop common standards for curricula, programs and so on is also being updated. Such a single state standard for training professional service education professionals in Ukraine has already been established. He, as we know, should be the basis of the curricula of all, with the exception of higher education institutions that issue state diplomas.

Conclusions. The content of the professional training of specialists is defined in such component of the state industry standard as the educational and professional training program. Therefore, the analysis of the state of professional training of future specialists in the field of service in forming their readiness for professional interaction with service consumers shows that the practical training does not correspond to the requirements of employers, namely: insufficient ability to deal positively with conflict situations; uncertainty about professional activities.

Drawing on the study of scientific literature, under the readiness for professional activity, we will understand the integrative personal education that is the regulator and condition for successful professional activity of future social workers. During the scientific analysis of the category "readiness for professional activity" we have found that the process of formation of readiness for professional activity can be purposefully managed, if appropriate to build a model of educational process, to create effective psychological and pedagogical conditions and to use pedagogically appropriate technologies.

\section{References:}

1. Boyko OV Formation of readiness for management activity in future masters of military-social management: diss. ... Cand. ped. Sciences: 13.00.04 / OV Boyko; IPPPO APS of Ukraine. - K., 2005. - 252 p.

2. Durai-Novakova K.M. Formation of professional readiness for pedagogical activity / KMDurai-Novakov. - M .: Politizdat, 1983. - 356 p

3. Gerasimenko VG Transformation of international tourism and its reflection in the process of training / VG Garasimenko // Regional collection of scientific papers on economics. - Donetsk: Prometheus, 1999. - Issue. 1. - P. 114-120.

4. Resolution of the Cabinet of Ministers of Ukraine "On approval of the list of branches of knowledge and specialties for which higher education applicants are trained" dated 29.04.2015, No. 266 [Electronic resource]. - Access mode: http://zakon0.rada.gov.ua/laws/show/266-2015-\%D0\%BF 
5. Sakun LV Theory and practice of training specialists in tourism in developed countries of the world: [monograph] / LV Sakun. - K .: MAUP, 2004. - 285 p. 8. Fedorchenko VK Training of specialists in tourism: Theoretical and methodological aspects: [monograph] / Vladimir Kirilovich Fedorchenko. - K .: Higher School, 2002. - 247 p 